\title{
PENGARUH KINERJA KEUANGAN DAN MAKROEKONOMI TERHADAP RETURN SAHAM PERUSAHAAN PROPERTY DAN REAL ESTATE DI BEI PERIODE 2014-2017
}

\author{
Rina Nugraheni \\ Universitas Negeri Surabaya \\ rinanugraheni@mhs.unesa.ac.id \\ R.A. Sista Paramita \\ Universitas Negeri Surabaya \\ sistaparamita@unesa.ac.id
}

\begin{abstract}
This study aims to provide empirical evidence related to the effect of financial and macroeconomic performance on stock returns. Samples were taken using a purposive sampling technique and found 171 companies that routinely report financial reports, did not do a stock split, and did not conduct an IPO during 2014-2017. The data analysis technique used in this study was a multiple regression analysis using the SPSS 23 application. The results showed that simultaneous independent variables influence stock returns. Partial test results in this study showed that financial performance variables that were proxied by the Current ratio, PER, DER, PBV, and TATO did not affect stock returns, while macroeconomics (inflation and exchange rates) had a significant negative effect on stock returns. Macroeconomic factors are more influential on stock returns and responded by investors directly suitable for short-term investments, while financial performance requires time to be responded by stock returns and more suitable for long-term investments.
\end{abstract}

Keywords: exchange rates; financial performance; inflation; property and real estate sector; stock returns.

\section{PENDAHULUAN}

Kemajuan perekonomian dan penunjang ekonomi di satu negara dapat dilihat dari pasar modal (Bisara \& Lailatul, 2015). Untuk memajukan pasar modal dapat dilakukan dengan meningkatkan aktifitas investasinya (IDX, 2019). Menurut Tandelilin (2010:61) pelaksanaan investasi di pasar modal dilakukan dalam rangka menghubungkan investor atau pemilik modal dengan perusahaan atau institusi pemerintah. Investor memasuki pasar modal karena ingin memanfaatkan uangnya demi mendapat keuntungan, sedangkan perusahaan yang menjual sahamnya di pasar modal membutuhkan aset untuk menjalankan perusahaan atau proyeknya. Dalam rangka meningkatkan investasi Pemerintah Indonesia mengampanyekan program Yuk Nabung saham melalui PT. Bursa Efek Indonesia (IDX, 2019).

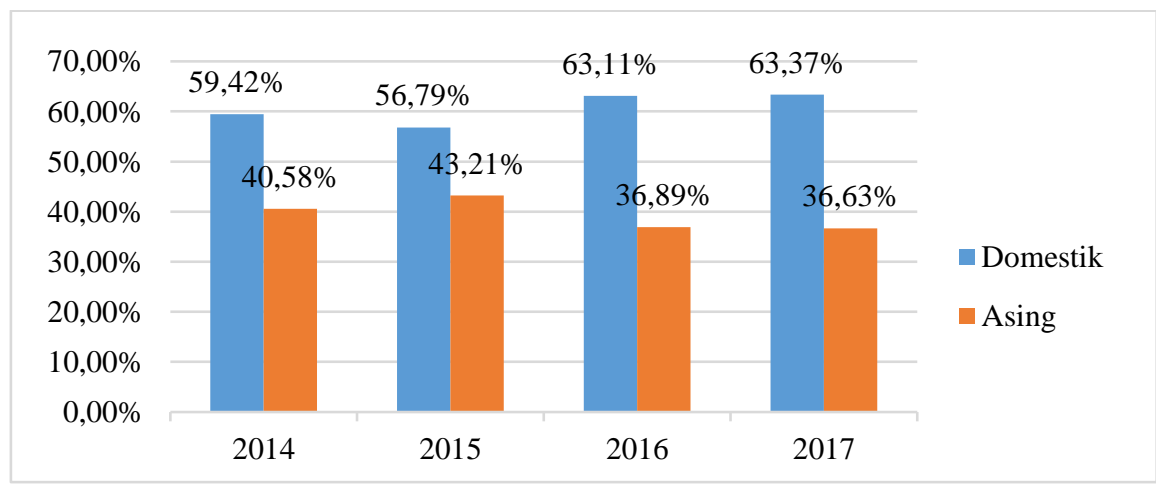

Sumber: ojk.go.id (2019, data diolah)

\section{Gambar 1. NILAI PERDAGANGAN SAHAM BERDASARKAN TIPE INVESTOR}

Dapat dilihat dari tahun 2015 sejak diadakannya program "Yuk Nabung Saham" jumlah investor domestik semakin bertambah setiap tahunnya (OJK, 2019). Analisis investasi yang dilakukan oleh investor dapat dikatakan berhasil mencapai tujuan jika investor memperoleh keuntungan sama seperti yang diekspektasikan atau bahkan melebihi ekspektasi (Nuryana, 2013). 
Rina Nugraheni \& R.A. Sista Paramita. Pengaruh Kinerja Keuangan dan Makroekonomi terhadap Return Saham Perusahaan Property dan Real Estate di BEI Periode 2014-2017

Seorang investor dalam berinvestasi ada yang menyukai risiko tinggi karena menginginkan return saham yang lebih banyak, sementara itu ada pula yang menghindari risiko dan mendapatkan return saham yang tidak terlalu besar, karena risiko dan return saham memiliki hubungan satu arah sesuai dengan hasil penelitian dari (Yunita, Efni, \& Kamaliah, 2016). Untuk memperkirakan besarnya risiko investasi diperlukan laporan keuangan dari perusahaan agar pemilik modal dapat memiliki keputusan yang tepat dalam mengelola saham yang dimiliki atas perusahaan tersebut (Hidayat, 2016). Kasmir (2014:106) memaparkan bahwa analisis yang dapat dipakai pada laporan keuangan sebanyak enam rasio, enam rasio tersebut antara lain rasio likuiditas, rasio leverage, rasio aktifitas, rasio profitabilitas, rasio pertumbuhan dan rasio penilaian yang dapat dikelompokkan dan digunakan sesuai dengan kebutuhan. Selain itu, terdapat rasio pasar dari Brigham \& Houston (2007:150) untuk melengkapi rasio kinerja keuangan dengan perhitungan yang didapat dari luar laporan keuangan perusahaan.

Pelaksanaan investasi di pasar modal dilakukan dalam rangka menghubungkan investor atau pemilik modal dengan perusahaan atau institusi pemerintah. Investor atau pemilik modal memasuki pasar modal karena ingin memanfaatkan dananya demi mendapat keuntungan, sedangkan perusahaan yang menjual sahamnya di pasar modal membutuhkan dana untuk menjalankan perusahaan atau proyeknya. Return yang akan didapatkan oleh investor bentuknya dapat berupa yield dan capital gain/loss. Yield atau devidend yield adalah pengembalian hasil atau pembagian keuntungan profit perusahaan yang diperoleh investor dari saham yang sudah dibeli dan didapatkan setiap tahun (Tandelilin, 2010:52). Investor akan mendapatkan capital gain jika harga saham yang sudah dibelinya meningkat atau lebih mahal dari harga yang sebelumnya sudah dibelikan tetapi sebaliknya investor akan mendapatkan capital loss jika harga saham yang sudah dibeli sebelumnya berkurang atau lebih murah pada periode saat ini (Tandelilin, 2010:45).

\section{Tabel 1.}

\section{RETURN SAHAM PER SEKTOR}

\begin{tabular}{lccc}
\hline \multicolumn{1}{c}{ Sektor } & $\mathbf{2 0 1 6}$ & $\mathbf{2 0 1 7}$ & $\mathbf{2 0 1 8}$ \\
\hline Property, Real estate & $5 \%$ & $-4 \%$ & $-18 \%$ \\
Basic Industry \& Chemicals & $32 \%$ & $28 \%$ & $52 \%$ \\
Finance & $18 \%$ & $41 \%$ & $33 \%$ \\
Trade, Services and Investment & $1 \%$ & $7 \%$ & $-4 \%$ \\
Infrastructure, Utilities and Trasportation & $8 \%$ & $12 \%$ & $-2 \%$ \\
Manufacturing & $221 \%$ & $22 \%$ & $10 \%$ \\
Miscellaneous Industry & $30 \%$ & $1 \%$ & $-9 \%$ \\
Mining & $71 \%$ & $15 \%$ & $42 \%$ \\
Agriculture & $8 \%$ & $-13 \%$ & $-15 \%$ \\
\hline Sumber:
\end{tabular}

Sumber: idx.co.id (2019, data diolah)

Tabel Return saham per sektor memperlihatkan di sepanjang tahun 2016 sampai 2018 sektor Property dan Real estate adalah yang paling terlihat angka penurunannya dibandingkan dengan sektor yang lainnya. Menurunnya angka return saham dari sektor Property dan Real Estate mengindikasikan bahwa harga saham juga turun (IDX, 2019). Artinya terdapat penurunan harga saham cukup besar pada sektor Property dan Real Estate sehingga hal tersebut tidak sejalan dengan meningkatnya nilai perdagangan saham serta investor domestik yang meningkat. Di mana seharusnya tingginya nilai yang diperdagangkan dan naiknya jumlah investor akan membuat permintaan akan saham menjadi meningkat dan dapat menaikkan harga saham (Effendi \& Hermanto, 2017).

Laporan keuangan menjadi informasi atau hal yang bisa memengaruhi return saham dan bisa digunakan oleh investor sebagai bahan pertimbangan dalam menentukan pilihan saham untuk investasinya. Sumber informasi bisa didapatkan oleh investor yaitu dari dalam (internal) perusahaan serta dari luar (eksternal) perusahaan. Hal-hal atau informasi internal yang memengaruhi return saham ialah berasal dari data perusahaan yang berupa laporan keuangan di mana dapat diakses oleh pihak yang membutuhkan di website resmi BEI, sedangkan informasi yang didapatkan dari luar perusahaan ialah tingkat inflasi dan nilai tukar di sebuah negara (makro ekonomi) (Hidayat, 2016). 
Current ratio berdasarkan buku Brigham \& Houston (2007:134) ialah angka perbandingan yang dapat melihat sejauh mana kemampuan atau likuiditas dari perusahaan mampu untuk dapat melunasi utang lancarnya. Ulupui (2007) mengatakan jika current ratio dapat memberikan dampak dengan jelas dengan arah yang bagus atau positif kepada variabel Y yaitu return saham, sedangkan Martani (2009) mengatakan dalam jurnalnya jika current ratio memberikan dampak yang negatif dengan dampak yang terlihat jelas kepada return saham. Lain halnya dari jurnal Anisa (2015) dan Budialim (2013) yang menghasilkan penelitian bahwa current ratio tidak terpengaruh terhadap return saham.

Price Earning Ratio ialah rasio yang dapat memperlihatkan seberapa tinggi harga yang mau dibayarkan dari pemilik modal demi memiliki profit yang dimiliki suatu perusahaan (Tandelilin, 2010:385). Prasetyorini (2013) dan Artaya (2014) mengatakan jika PER dapat memberikan dampak yang bagus atau positif kepada return saham dengan pengaruh yang terlihat jelas. Pendapat yang berlainan dihasilkan oleh Mathilda (2012) di mana PER memengaruhi return saham secara negatif dan signifikan, sementara Anisa (2015) menghasilkan PER yang tidak dapat memengaruhi pergerakan dari return saham.

Debt to Equity Ratio ialah nilai yang dihasilkan dari rasio pertimbangan atau proporsi jumlah pinjaman dana perusahaan atas seluruh modalnya (Kasmir, 2014:158). Karim (2015) dan Hidayat (2016) dalam penelitiannya menyatakan bahwa DER tidak dapat memengaruhi naik turunnya return saham. Marlina \& Sari (2009) dan Sutriani (2014) memiliki hasil yang berbeda yaitu DER dapat memengaruhi return saham dengan arah yang positif dan signifikan, sementara Arista \& Astohar (2012) memiliki pendapat pada jurnalnya yang mengatakan variabel $\mathrm{X}$ atau DERnya memengaruhi return saham secara negatif dan signifikan.

Price to Book Value ialah rasio yang didapatkan dengan membandingkan harga saham di pasar dengan nilai buku dari saham tersebut (Brigham \& Houston, 2007:151). Arista \& Astohar (2012) dan Martani et al. (2009) dalam penelitiannya mengatakan bahwa PBV berpengaruh secara positif dan signifikan terhadap return saham. Untuk hasil yang mengatakan bahwa PBV memengaruhi return saham dengan arah negatif dan signifikan dihasilkan dari jurnal Alkaditiya (2017) sedangkan Anisa (2015) dan Mathilda (2012) menghasilkan PBV yang tidak dapat memengaruhi return saham.

Total Asset Turnover ialah rumus perhitungan yang dapat menunjukkan dalam mengelola perusahaan apakah seluruh aset yang dikerahkan untuk menghasilkan penjualan digunakan perusahaan dengan efisien dan dapat menghasilkan penjualan yang maksimal (Kasmir, 2014:185). Alkaditiya (2017) dalam penelitiannya mengatakan bahwa TATO berpengaruh positif dan terlihat jelas kepada return saham, sementara itu Martani et al. (2009) mengatakan bahwa TATO berdampak negatif dan signifikan kepada return saham. Hasil yang berbeda juga dihasilkan oleh Ulupui (2007) karena dalam penelitiannya TATO tidak bisa memberikan dampak kepada return saham.

Inflasi pada jurnal penelitian ini juga bisa diartikan sebagai informasi yang dapat diperoleh dari luar perusahaan, di mana menurut Tandelilin (2010:342) ialah kondisi di mana harga-harga dari barang secara umum menjadi semakin mahal dan biasanya terjadi pada saat kondisi ekonomi suatu negara kurang baik. Mahilo (2015) dan Wiradharma \& Sudjarni (2016) dalam penelitiannya mengatakan bahwa inflasi tidak dapat berdampak kepada return saham. Pernyataan yang berbeda didapatkan dari jurnal Rusliati \& Fathoni (2011) dan Khan (2017) yang mengatakan jika ternyata inflasi dapat memberikan dampak negatif yang jelas, sementara Rahman \& Arfianto (2016) dan Zakaria (2015) memiliki hasil jurnal di mana inflasi dapat memberikan dampak yang positif dan jelas kepada return saham.

Nilai tukar menurut Sukirno (2010:397) diartikan sebagai berapa banyaknya jumlah uang yang dibayarkan agar bisa mendapatkan satu unit mata uang dari luar negeri. Rahman \& Arfianto (2016) dan Prasetioningsih (2015) dalam penelitiannya mengatakan bahwa nilai tukar memengaruhi return saham secara negatif dan signifikan. Hasil yang berbeda dihasilkan oleh Hanurat (2013) dan Karim (2015) yang menyatakan bahwa nilai tukar berpengaruh negatif dan signifikan, sementara (Kurniadi (2013) 
Rina Nugraheni \& R.A. Sista Paramita. Pengaruh Kinerja Keuangan dan Makroekonomi terhadap Return Saham Perusahaan Property dan Real Estate di BEI Periode 2014-2017

dan Wiradharma \& Sudjarni (2016) menghasilkan penelitian nilai tukar yang tidak berpengaruh terhadap return saham.

Tujuan dari penelitian ini ialah untuk mengetahui pengaruh dari kinerja keuangan dan makroekonomi terhadap return saham perusahaan bidang property dan real estate yang terdaftar di BEI. Data yang digunakan untuk penelitian mulai dari tahun 2014 sampai tahun 2017.

\section{KAJIAN PUSTAKA DAN PENGEMBANGAN HIPOTESIS}

\section{Signalling Theory}

Investor di dalam mempertimbangkan baik buruknya suatu perusahaan untuk bisa dipilihnya dalam menanamkan modal melihatnya melalui informasi dari laporan keuangan perusahaan, sehingga laporan keuangan yang bagus akan dipandang bagus pula perusahaannya oleh investor (Sunardi, 2010). Tandelilin (2010:364) dalam bukunya mengatakan bahwa laporan keuangan sangat berguna karena informasi yang diberikan kepada investor akan bisa digunakan dalam menganalisis keputusan untuk membeli dan menjual saham mereka. Demi menghindari risiko kerugian dan bisa mendapat keuntungan maka investor perlu mengartikan informasi yang didapat apakah bersifat positif atau negatif bagi investasinya. Informasi yang dilihat oleh investor pada laporan keuangan yang diterbitkan oleh emiten dapat berisikan informasi atau hal yang berguna sebab bisa digunakan sebagai alat pertimbangan dalam berinvestasi (Ulupui, 2007).

\section{Return Saham}

Penelitian ini menggunakan konsep return capital gain dengan satuan waktu tahunan. Return saham yang digunakan pada penelitian ini yaitu capital gain di mana menurut Abdullah, Soedjatmiko, \& Sari, (2016) pengertiannya adalah perbedaan nilai atau selisih dari nilai jual saham pada waktu sekarang dengan nilai jual pada waktu sebelumnya, dan dapat dihitung dengan rumus (1) (Tandelilin, 2010:52):

Return Saham $=\frac{\mathrm{P}_{\mathrm{t}}-\mathrm{P}_{\mathrm{t}-1}}{\mathrm{P}_{\mathrm{t}-1}}$.

Keterangan:

$\mathrm{Ri}=$ return saham i pada periode $\mathrm{t}$.

$\mathrm{Pt} \quad=$ harga penutupan saham i pada periode $\mathrm{t}$.

$\mathrm{P}(\mathrm{t}-1)=$ harga penutupan saham i pada periode sebelumnya.

\section{Rasio Likuiditas (Current ratio)}

Kasmir (2014:110) menyatakan bahwa rasio likuiditas dapat menunjukkan seperti apa kekuatan aset perusahaan dalam rangka menangani utang-utang jangka pendek atau lancar yang biasanya jatuh tempo kurang dari satu tahun. Pengertian current ratio menurut Brigham \& Houston (2007:134) ialah perbandingan atau rasio yang dapat melihat sejauh mana kemampuan atau likuiditas dari perusahaan mampu untuk dapat melunasi utang lancarnya. Jika perusahaan memiliki aset lancar yang banyak terdapat beberapa keuntungan yaitu dapat dengan membayar utang lancarnya, memiliki cadangan dana yang mudah untuk dicairkan, sehingga perusahaan dengan likuiditas yang tinggi memiliki kemungkinan terhindar dari kerugian. Semakin likuid atau lancar suatu dana di perusahaan, dapat diartikan juga bahwa perusahaan memiliki kinerja yang semakin baik dan akan memunculkan kepercayaan bagi investor untuk membeli saham. Current ratio digunakan sebagai proksi dari rasio likuiditas sebagai variabel bebas pada penelitian ini. Cara untuk menghitung current ratio ialah seperti rumus (2).

Current ratio $=\frac{\text { Aset Lancar }}{\text { Utang Lancar }}$

\section{Rasio Leverage (Debt to Equity ratio)}

Rasio leverage dalam jurnal di sini dipergunakan sebagai alat untuk memperlihatkan jumlah yang dihasilkan dari manfaat pengelolaan aset perusahaan dengan sumber dana dari utang. Debt to equity 
ratio atau DER dipilih untuk digunakan sebagai wakil dari rasio leverage sebagai variabel bebas pada penelitian ini. DER berfungsi untuk dapat memperlihatkan berapa banyak modal asli perusahaan yang digunakan untuk jaminan sebagai pelunas utang. DER ialah rasio atau angka perbandingan yang dapat dimanfaatkan sebagai alat ukur dari jumlah utang perusahaan dengan ekuitas/modal perusahaan. Semakin tinggi nilai DER maka semakin menunjukkan bahwa tingkat pinjaman dari eksternal yang digunakan oleh perusahaan juga semakin meningkat. Tingginya jumlah pinjaman dari luar yang diperoleh perusahaan dapat mengakibatkan semakin tingginya risiko akan terjadinya kegagalan pada perusahaan. DER didapatkan dengan menggunakan rumus nomor (3) (Kasmir, 2014:158).

$\mathrm{DER}=\frac{\text { Total Utang }}{\text { Ekuitas }}$

\section{Rasio Aktifitas (Total Asset Turnover)}

Pengertian dari rasio aktifitas ialah perhitungan yang digunakan agar dapat memperlihatkan keefektifan dan keefisienan perusahaan di dalam mengelola seluruh aset milik perusahaan. Rasio aktifitas yang digunakan ialah total asset turnover atau biasa disebut TATO. Di mana total asset turnover atau TATO ialah rasio perbandingan yang dipergunakan untuk mengetahui keefisienan pengelolaan dari seluruh aset perusahaan yang difungsikan untuk mengelola aktifitas penjualan perusahaan (Kasmir, 2014:185). Rasio TATO dengan hasil yang tinggi bisa dikatakan bahwa aset yang dikelola oleh emiten dapat menghasilkan penjualan dengan jumlah yang besar (efisien), jadi dapat diartikan bahwa pengelola perusahaan berhasil dalam mengelola asetnya dengan baik dan dapat meningkatkan harapan untuk mendapatkan laba (Alkaditiya, 2017). TATO dapat dihitung dengan rumus seperti nomor (4) (Brigham \& Houston, 2007:139).

$\mathrm{TATO}=\frac{\text { Penjualan }}{\text { Total Aset }}$

\section{Rasio Pasar (Price Earning Ratio)}

Rasio pasar biasanya digunakan oleh pemilik modal/investor dalam menganalisis kondisi perusahaan berdasarkan harga sahamnya dengan dikaitkan dengan keuntungan, arus kas dan nilai bukunya (Brigham \& Houston, 2007:150). Rasio pasar yang digunakan pada penelitian ini ialah price earning ratio atau PER di mana menurut Brigham \& Houston (2007:150) ialah rasio yang bisa menunjukkan berapa besar harga yang mau dibayarkan dari investor demi mendapat nilai laba yang sudah dihasilkan oleh perusahaan. PER dapat menunjukkan seberapa tinggi harga suatu saham yang berada di pasar modal dan dibandingkan dengan laba per sahamnya. Angka PER yang semakin tinggi mencerminkan bahwa kemampuan kerja perusahaan akan memiliki masa depan yang baik, dan dapat mendorong keinginan investor untuk menanamkan sahamnya (Artaya et al., 2014). Secara matematis dapat dihitung menggunakan perhitungan seperti nomor (5) (Brigham \& Houston, 2007:150).

$\mathrm{PER}=\frac{\text { Harga Saham }}{\text { Laba per Lembar saham }}$

\section{Rasio Pasar (Price to Book Value)}

Price to book value atau rasio PBV termasuk dalam salah satu dari rasio pasar dan dipergunakan pada penelitian ini sebagai variabel bebas. PBV menurut Brigham \& Houston (2007:151) dihitung dengan membagi harga saham dari pasar dengan nilai buku dari setiap lembar saham. Nilai PBV yang kian banyak bagi investor dianggap bahwa saham perusahaan dikelola dengan kinerja yang baik dan terbukti dari harga saham yang tinggi di pasar modal. PBV ialah perbandingan dari nilai jual saham di pasar modal dengan nilai buku dari saham tersebut yang berasal dari laporan keuangan sehingga kita dapat memperoleh informasi dari rasio pasar tersebut. Hasil dari perbandingan rumus PBV jika menghasilkan angka yang tinggi artinya harga saham juga terbilang tinggi atau mahal di mana artinya seman banyak penanam modal yang mengincar atau menawar saham perusahaan yang bersangkutan karena dianggap memiliki masa depan yang bagus (Sugiarto, 2011). PBV dapat dihitung dengan rumus nomor (6) (Brigham \& Houston, 2007:152): 
Rina Nugraheni \& R.A. Sista Paramita. Pengaruh Kinerja Keuangan dan Makroekonomi terhadap Return Saham Perusahaan Property dan Real Estate di BEI Periode 2014-2017

$\mathrm{PBV}=\frac{\text { Harga Pasar Saham }}{\text { Nilai Buku per Saham }}$

\section{Inflasi}

Menurut BPS (2019), jika terjadi kenaikan suatu harga barang-barang dan jasa secara umum serta terjadi secara berkelanjutan maka hal tersebut dinamakan inflasi. Pengertian inflasi berdasarkan dari buku Tandelilin (2010:342) ialah yaitu terjadinya harga jual barang-barang yang mengalami peningkatan secara bersamaan dan seluruhnya, kondisi ini cenderung terjadi pada saat ekonomi suatu negara sedang panas. Tandelilin (2010:343) mengatakan bahwa terjadinya inflasi bisa mengakibatkan berkurangnya nilai dari hasil pendapatan riil dari hasil investasinya. Penelitian ini menggunakan Indeks Harga Konsumen atau IHK karena dapat mengetahui angka dari rata-rata pergerakan atau fluktuasi dari nilai jual suatu barang dan jasa yang pada waktu tertentu dibeli oleh masyarakat pada umumnya. Jika inflasi semakin naik di suatu negara maka nilai uang di negara tersebut mengalami penurunan. Naiknya harga produk akan membuat biaya yang dikeluarkan perusahaan juga meningkat sehingga dapat mengurangi laba yang nantinya akan dihasilkan (Rusliati \& Fathoni, 2011). Perhitungan nilai inflasi pada penelitian ini dirumuskan sebagai berikut dituliskan di nomor (7).

Inflasi $=\frac{\mathrm{IHK}_{\mathrm{t}}-\mathrm{IHK}_{\mathrm{t}-1}}{\mathrm{IHK}_{\mathrm{t}-1}}$.

Keterangan:

IHK $\mathrm{t}=$ Indeks Harga konsumen tahun $\mathrm{t}$

$\operatorname{IHK}(\mathrm{t}-1)=$ Indeks Harga Konsumen tahun $\mathrm{t}-1$

\section{Nilai Tukar}

Menurut buku dari Sukirno (2010:397) nilai tukar merupakan nilai atau berapa banyak mata uang lokal untuk dapat disamakan dengan mata uang negara lain. Amrillah (2016) dalam penelitiannya mengatakan bahwa perusahaan dengan kegiatan impor dan utang luar negeri akan mengalami kesulitan pada saat terjadi penurunan nilai kurs dari rupiah terhadap dolar (dolar lebih mahal), dikarenakan rupiah yang dikeluarkan akan menjadi lebih banyak dari sebelumnya dan dapat mengakibatkan berkurangnya keuntungan yang dihasilkan begitu pula sebaliknya. Penurunan nilai dari kurs mata uang lokal bisa memberikan dampak yang kurang baik bagi perusahaan yang memiliki utang luar negeri karena harus membayar utang dan bunganya dengan mata uang asing sedangkan barang dari perusahaan dipasarkan di negeri sendiri, jika hal tersebut terjadi maka dapat mengakibatkan harga saham perusahaan tersebut menjadi turun dipastikan turun dan berdampak pada return saham yang juga turun (Riantani \& Tambunan, 2013). Nilai tukar didapatkan dengan menggunakan rumus nomor (8).

Nilai Tukar $=\frac{\mathrm{K}_{\mathrm{t}}-\mathrm{K}_{\mathrm{t}-1}}{\mathrm{~K}_{\mathrm{t}-1}}$

Keterangan:

$\mathrm{Kt}=$ Kurs tahun $\mathrm{t}$

$\mathrm{Kt}_{-1}=$ Kurs tahun sebelumnya

\section{Hubungan antar Variabel}

Current ratio dengan angka yang tinggi menandakan bahwa perusahaan tidak kesulitan untuk menangani utang-utang jangka pendeknya dan masih memiliki sisa dana cadangan untuk kegiatan perusahaan (Erari, 2014). Ulupui (2007) menyatakan bahwa current ratio berpengaruh positif dikarenakan investor lebih memilih perusahaan dengan kemampuan membayar utang yang lebih tinggi, jadi investor akan merasa aman jika memilih perusahaan dengan aset yang benar-benar lancar, sehingga akan banyak yang meminta saham perusahaan tersebut di pasar modal. Naiknya permintaan saham akan meninggikan harga saham beserta returnnya.

H1: Current ratio (CR) berpengaruh terhadap return saham perusahaan sektor property dan real estate periode 2014-2017. 
PER yang tingi menandakan bahwa harga saham juga tinggi dan investor menganggap bahwa pertumbuhan perusahaan tersebut di masa depan akan lebih baik (Hayati, 2010). Penelitian dari Artaya et al. (2014) menghasilkan rasio PER yang dijadikan sebagai tolak ukur untuk keuntungan yang akan perusahaan peroleh di masa depan nanti. Jika perusahaan menghasilkan keuntungan yang besar besar kemungkinan nilai PER yang nantinya dihitung akan mengikuti semakin besar pula. Informasi yang dianggap investor bagus tersebut akan menambah jumlah saham yang akan diminta oleh investor, sehingga akan membuat harga saham menjadi meningkat dan akan diiringi dengan return sahamnya yang juga bertambah besar.

H2: Price Earning Ratio (PER) berpengaruh terhadap return saham perusahaan sektor property dan real estate periode 2014-2017.

\section{Pengaruh DER terhadap Return Saham}

Kegunaan dari rasio DER yaitu dapat melihat seberapa banyak perbandingan penggunaan utang milik perusahaan dibandingkan dengan total modal sendiri/ekuitas dari perusahaan untuk mengelola perusahaannya. Angka DER yang besar mengindikasikan bahwa risiko yang akan ditanggung oleh emiten juga ikut semakin besar sejalan dengan jumlah utang yang besar (Karim, 2015). Angka DER yang besar juga akan cenderung tidak disukai oleh pemilik modal karena demi menghindari risiko yang bisa terjadi kedepannya. Kurang berminatnya investor dengan saham yang memiliki angka DER yang besar dapat membuat harga saham beserta return saham perusahaan yang bersangkutan menjadi turun.

H3: Debt to Equity Ratio (DER) berpengaruh terhadap return saham perusahaan sektor property dan real estate periode 2014-2017.

Arti dari PBV ialah perusahaan yang memiliki keuntungan, arus kas dan pertumbuhan yang menjanjikan akan cenderung dipandang dengan lebih baik oleh investor dan akan dijual dengan PBV yang lebih tinggi daripada perusahaan dengan keuntungan yang kecil (Brigham \& Houston, 2007:152). Rasio PBV dengan hasil yang besar dapat mencerminkan kemampuan perusahaan yang bagus sehingga dapat membuat pemilik modal berkeinginan agar bisa menanamkan dananya kepada perusahaan tersebut. Naiknya jumlah investor yang berminat pada saham suatu perusahaan dapat membuat nilai jual saham menjadi semakin tinggi dan diiringi dengan return sahamnya yang juga naik.

H4: Price to Book Value (PBV) berpengaruh terhadap return saham perusahaan sektor property dan real estate periode 2014-2017.

Deitiana (2011) menyatakan bahwa variabel TATO ialah rumus perbandingan yang dihitung agar dapat melihat seberapa banyaknya keuntungan atau profit yang dapat dihasilkan oleh perusahaan dengan memaksimalkan penggunaan aktifitas dari total aset untuk menghasilkan penjualan. Alkaditiya (2017) dalam jurnalnya mengatakan bahwa semua jenis perusahaan dengan nilai TATO yang tinggi menggambarkan bahwa asetnya berhasil menghasilkan penjualan, sehingga peluang untuk mendapatkan keuntungan juga akan semakin besar. Angka TATO yang semakin tinggi akan direspon dengan baik oleh pemilik modal karena artinya akan ada lebih banyak keuntungan yang bisa didapatkan oleh investor sehingga memengaruhi banyaknya jumlah saham yang diminta oleh investor yang mengakibatkan harga saham perusahaan meningkat di pasar modal dan harapan naiknya pengembalian keuntungan dari saham yang sudah dibeli pun akan meningkat (Alkaditiya, 2017).

H5: Total Asset Turnover (TATO) berpengaruh terhadap return saham perusahaan sektor property dan real estate periode 2014-2017.

Besarnya angka inflasi dapat mengakibatkan bertambahnya beban biaya bagi perusahaan dan menurunkan daya beli, sehingga akan mengurangi jumlah keuntungan yang didapatkan perusahaan (Amrillah, 2016). Laba perusahaan yang kecil akan membuat pemilik modal kurang berminat dalam menanamkan modalnya sehingga dapat memberikan dampak atau respon bagi return saham dengan 
Rina Nugraheni \& R.A. Sista Paramita. Pengaruh Kinerja Keuangan dan Makroekonomi terhadap Return Saham Perusahaan Property dan Real Estate di BEI Periode 2014-2017

turunnya harga di pasar modal dan penurunan return saham yang juga akan mengikuti (Tandelilin, 2010:343).

H6: Inflasi berpengaruh terhadap return saham perusahaan sektor property dan real estate periode 2014-2017.

Penurunan nilai dari kurs mata uang lokal bisa memberikan dampak yang kurang baik bagi perusahaan yang memiliki utang luar negeri karena harus membayar utang dan bunganya dengan mata uang asing sedangkan barang dari perusahaan dipasarkan di negeri sendiri, nilai jual saham perusahaan tersebut dapat dipastikan turun dan berdampak pada return saham yang juga turun (Riantani \& Tambunan, 2013).

H7: Nilai Tukar berpengaruh terhadap return saham perusahaan sektor property dan real estate periode 2014-2017.

\section{METODE PENELITIAN}

Penelitian di dalam jurnal ini termasuk kuantitatif dengan analisis regresi berganda sebagai metode yang digunakan. Penelitian ini menggunakan sektor property dan real estate dan jangka waktu penelitian selama empat tahun yang dimulai dari tahun 2014 sampai 2017. Sampel penelitian diambil menggunakan cara purposive sampling di mana dalam pengambilan sampel untuk penelitian dibutuhkan beberapa persyaratan yang sengaja dibuat dengan maksud sampel penelitian yang akan didapatkan nantinya dapat mewakilkan data. Kriteria atau syarat yang sudah ditetapkan untuk mengambil sampel ialah perusahaan yang terdaftar di dalam sektor property dan real estate; perusahaan yang secara rutin melaporkan laporan keuangan selama periode penelitian tahun 2014-2017; perusahaan yang tidak menyelenggarakan stock split selama periode penelitian tahun 2014-2017; perusahaan yang tidak melakukan IPO selama periode 2014-2017. Sebanyak 49 sampel perusahaan didapatkan dari purposive sampling dan menjadi 196 karena digandakan empat tahun sesuai dengan periode penelitian. Penelitian ini menggunakan aplikasi SPSS 23.0 untuk menganalisis data penelitian.

\section{HASIL DAN PEMBAHASAN}

\section{Uji Normalitas}

Fungsi dari uji normalitas menurut Ghozali (2016:154) ialah untuk memperlihatkan apakah model regresi yang digunakan variabel residualnya mempunyai penyebaran yang normal. Uji yang digunakan oleh penelitian ini dalam melakukan uji normalitas yaitu uji Kolmogorov-Smirnov di mana hasil yang dinyatakan memiliki distribusi yang normal yaitu memiliki nilai lebih dari 0,05 . Nilai signifikansi yang dihasilkan pada penelitian ini melalui aplikasi SPSS yaitu sebesar 0,200 di mana nilai tersebut sudah melebihi nilai 0,05 . Jadi bisa diartikan kalau variabel residualnya memiliki penyebaran data yang normal sehingga data penelitian lolos dari uji normalitas.

\section{Uji Multikolinearitas}

Tujuan dari uji multikolinearitas menurut Ghozali (2016:103) ialah untuk mendeteksi adanya korelasi diantara variabel-variabel bebas di dalam penelitian. Variabel bebas bisa dinyatakan lolos apabila nilai tolerance $>10 \%$ atau nilai VIF $<10$. Output yang dihasilkan dari SPSS menunjukkan bahwa variabelvariabel bebas penelitian ini menghasilkan nilai tolerance $>10 \%$ sementara untuk hasil nilai VIF $<10$, dengan demikian bisa dinyatakan lolos uji multikolinearitas.

\section{Uji Heterokedastisitas}

Tujuan dari uji heterokedastisitas menurut Ghozali (2016:134) ialah menunjukkan apakah varians dari residual mengalami ketidaksamaan dengan pengamatan lainnya. Penelitian ini menggunakan uji spearman rho dalam melihat heteroskedastisitas. Jika nilai dari tiap variabel yang dihasilkan melebihi 0,05 maka dinyatakan tidak terjadi heterokedastisitas. Nilai dari masing-masing variabel untuk uji spearman rho menghasilkan lebih dari 0,05 sehingga dapat dinyatakan lolos uji heterokedastisitas. 


\section{Autokorelasi}

Tujuan dari uji autokorelasi menurut Ghozali (2016:107) ialah untuk menunjukkan adanya hubungan dari residual periode $t$ dengan periode sebelumnya. Penelitian ini menggunakan uji durbin watson dalam menguji autokorelasi data penelitian. Nilai durbin watson yang dihasilkan oleh SPSS yaitu 1,912 sehingga dapat dijabarkan sebagai berikut 1,8320 > 1,912 > 2,168. Dari syarat pengambil keputusan tersebut maka dapat dikatakan bahwa data penelitian lolos uji autokorelasi.

\section{Hasil Uji Statistik (Uji F)}

Uji statistik F menunjukkan bahwa pada penelitian di sini didapatkan nilai $\mathrm{F}$ hitung sebanyak 8,833 dengan 0,000 sebagai nilai signifikansinya. Nilai signifikansi yang tidak lebih besar dari dari 0,05 membuktikan kalau variabel bebas yakni current ratio, PER, DER, PBV, TATO, inflasi dan kurs secara bersamaan memberikan dampak kepada return saham perusahaan sektor property dan real estate periode tahun 2014-2017.

Tabel 2.

HASIL UJI REGRESI LINEAR BERGANDA

\begin{tabular}{|c|c|c|c|c|c|}
\hline \multicolumn{6}{|c|}{ Coefficients $^{\mathrm{a}}$} \\
\hline \multirow{2}{*}{ Model } & \multicolumn{2}{|c|}{ Unstandardized Coefficients } & \multirow{2}{*}{$\begin{array}{c}\text { Standardized Coefficients } \\
\text { Beta }\end{array}$} & \multirow{2}{*}{$\mathbf{t}$} & \multirow{2}{*}{ Sig. } \\
\hline & B & Std. Error & & & \\
\hline (Constant) & 144 & ,092 & & 1,563 &, 120 \\
\hline $\mathrm{CR}$ &,- 023 & ,019 &,- 087 & $-1,164$ & ,246 \\
\hline PER &,- 001 & 001 &,- 075 & $-1,062$ & ,290 \\
\hline DER &,- 023 & 057 &,- 034 &,- 404 & 687 \\
\hline PBV & 306 & .164 & 146 & 1,871 & 063 \\
\hline TATO & 010 & 010 &, 073 & 1,038 & ,301 \\
\hline INFLASI & $-2,277$ & ,319 &,- 565 & $-7,135$ & ,000 \\
\hline KURS & $-1,648$ &, 512 &,- 253 & $-3,217$ & 002 \\
\hline
\end{tabular}

Sumber: Output SPSS 23.0

Berpengaruh tidaknya sebuah variabel dapat lihat dari nilai sig. yang $<0,05$ jika berpengaruh dan tidak berpengaruh jika >0,05. Tabel 2 memperlihatkan bahwa variabel yang dapat memengaruhi return saham ialah inflasi (X6) dan nilai tukar (X7) dengan masing-masing nilai dari variabel tersebut 0,000 dan 0,002 . Variabel kinerja keuangan yang dipergunakan untuk penelitian ini seluruhnya tidaklah dapat memberikan dampak kepada return saham sebab memiliki nilai sig. > 0,05. Variabel kinerja keuangan terdiri dari current ratio (X1), price earning ratio (X2), debt to equity ratio (X3), price to book value (X4), dan total asset turnover (X5). Berdasarkan tabel 2, didapatkan model regresi (9).

Return Saham =-2,277 inflasi -1,648 kurs $+\mathrm{e}$

\section{Pengaruh Current ratio (CR) terhadap Return Saham}

Uji t yang dihasilkan untuk variabel current ratio menyatakan bahwa $\mathrm{H}_{\mathrm{a}}$ ditolak dan $\mathrm{H}_{0}$ lah yang diterima. Secara parsial current ratio pada penelitian ini tidaklah memberikan dampak kepada return saham dan dianggap tidak mendukung dari Signalling Theory. Penelitian di sini memberikan pendapat atau hasil di mana mendukung penelitian dari Budialim (2013); Hanurat (2013) dan Mathilda (2012) yang semuanya memiliki hasil jurnal bahwasanya current ratio tidak mampu memengaruhi return saham.

Tidak berpengaruhnya CR terhadap return saham yaitu menurut Kasmir (2014:135) jika suatu perusahaan memiliki rasio lancar (current ratio) dengan angka yang sedikit, maka dapat diasumsikan jika perusahaan tidak akan memiliki kemampuan yang cukup untuk membayar kewajibannya. Pada penelitian ini data current ratio yang diolah memiliki klasifikasi likuid yang lebih sedikit daripada illikuid. Penelitian ini menggunakan rata-rata per sektor untuk menentukan likuid tidaknya kategori perusahaan yang berasal dari (Brigham \& Houston, 2007:135). Lebih banyak perusahaan yang menjadi 
Rina Nugraheni \& R.A. Sista Paramita. Pengaruh Kinerja Keuangan dan Makroekonomi terhadap Return Saham Perusahaan Property dan Real Estate di BEI Periode 2014-2017

sampel pada penelitian ini tidak memiliki aset lancar yang dianggap memiliki kemampuan untuk membayar kewajiban lancarnya. Jadi jika CR rendah maka dapat menyebabkan investor tidak memilih perusahaan sehingga tidak ada pengaruhnya bagi return saham.

Bukti lain yang dapat mendukung bahwa $\mathrm{CR}$ tidak memengaruhi return saham ialah data dari perusahaan Sentul City Tbk. (BKSL) di mana pada tahun 2014, 2015 dan 2016 nilai CR yang dihasilkan yaitu 1,4930, 3,0673 dan 0,2077, akan tetapi fluktuasi dari nilai return saham adalah sebagai berikut $0,4500,-0,2328$ dan 0,0562 bisa diperhatikan bahwasanya pergerakan dari nilai return saham tidaklah terarah sesuai dengan nilai CR. Jadi dapat diketahui bahwa nilai current ratio tidaklah memengaruhi dari nilai return saham.

\section{Pengaruh Price Earning Ratio (PER) terhadap Return Saham}

Hasil uji t untuk variabel PER mendapatkan hasil Ha ditolak dan $\mathrm{H}_{0}$ diterima. Secara parsial PER pada penelitian ini tidaklah dapat memberikan dampak kepada return saham dan tidak dapat mendukung dari Signalling Theory. Penelitian ini yang menghasilkan hasil yang sama ialah Carlo (2014) dan Anisa (2015) yang menyatakan bahwa PER tidak dapat memberikan dampak kepada return saham.

Prasetyorini (2013) dalam jurnalnya menyatakan bahwa angka PER dengan nilai yang dihasilkan semakin besar juga membuat laba perusahaan tinggi karena semakin banyak profit juga dihasilkan untuk pemilik modal yang sudah berinvestasi sehingga PER dijadikan sebagai indikator bagi perkembangan kinerja emiten untuk tahun-tahun selanjutnya. Akan tetapi dalam penelitian ini nilai PER lebih banyak yang memiliki nilai di bawah rata-rata dan hanya sedikit yang berada di atas rata-rata. Hal inilah yang menyebabkan return saham tidak terpengaruh karena PER yang rendah artinya perusahaan dianggap kurang dapat memberikan jaminan untuk keuntungan yang lebih baik ke depannya, bagi investor, oleh karena itu investor tidak berinvestasi pada saham dengan PER yang rendah.

Bukti yang dapat mendukung dari hasil penelitian ini ialah salah satu data yang memperlihatkan bahwa fluktuasi dari nilai return saham perusahaan Pakuwon Jati Tbk (PWON) tidaklah mengikuti fluktuasi dari nilai PER baik dengan arah yang negatif maupun positif. Pada tahun 2014, 2015, dan 2016 nilai PER Pakuwon Jati Tbk ialah 9,5539, 17,0992 dan 16,1430 dengan nilai return saham masing-masing yaitu $0,8481,-0,1022$ dan 0,2500 .

\section{Pengaruh Debt to Equity Ratio (DER) terhadap Return Saham}

Nilai yang dihasilkan untuk uji t untuk variabel DER menyatakan bahwa Ha ditolak dan menerima $\mathrm{H}_{0}$. Secara parsial DER pada penelitian ini tidak dapat memberikan dampak atau pengaruh kepada return saham dan tidak sejalan dengan Signalling Theory. Penelitian terdahulu yang mendukung hasil penelitian ini ialah Husein \& Mahfud (2015); Prasetyorini (2013); Karim (2015) dan Budialim (2013) yang menghasilkan DER yang tidak bisa memberikan dampak kepada return saham.

Sampel perusahaan pada penelitian di sini memiliki lebih dari separuh yang mempunyai tingkat utang di atas rata-rata atau cukup tinggi, sehingga hal inilah yang menyebabkan return saham tidak terpengaruh karena tidak berminatnya investor pada saham dengan risiko yang tinggi. Jika dan yang digunakan sebagai Financial Leverages (diambilnya utang atau dana dari pihak luar/eksternal dalam rangka mengembangkan kegiatan dari operasional perusahaan) semakin besar, maka akan semakin besar pula utang jangka panjang perusahaan yang digunakan untuk membiayai kegiatan operasional perusahaan dan akan menjadikan laba operasional menjadi berkurang karena digunakan untuk menutupi utang jangan panjang beserta beban utangnya (Aditya \& Isnurhadi, 2013).

Data penelitian ini yang dapat menguatkan hasil pernyataan jika DER tidak memengaruhi nilai return saham. Salah satunya ialah perusahaan Adhi karya Persero (ADHI) yang masing-masing pada tahun 2014 sampai 2017 memiliki data DER sebagai berikut: 1,2952; 1,9021;0,9237; 2,6924 dengan nilai return saham yaitu: 0,$8719 ;-0,1906 ;-0,0332 ;-0,0072$. Artinya, fluktuasi dari DER tidaklah memengaruhi fluktuasi dari nilai return saham. Jadi data tersebut menguatkan pernyataan bahwa DER tidak memengaruhi return saham pada penelitian ini. 


\section{Pengaruh Price to Book Value (PBV) terhadap Return Saham}

Hasil uji t dari variabel PBV mendapatkan hasil Ha ditolak dan $\mathrm{H}_{0}$ diterima. Secara parsial PBV pada penelitian ini kurang bisa memberikan dampak yang dapat terlihat bagi return saham dan tidak bisa mendukung dari Signalling Theory. Jurnal dari penelitian yang mendukung penelitian ini ialah dari Anisa (2015); Suherman \& Siburian (2013) dan Mathilda (2012).

Terdapat lebih dari separuh sampel yang memiliki nilai PBV yang lebih tinggi dari rata-rata industri. Artinya harga saham dianggap terlalu mahal oleh investor karena tidak sebanding dengan nilai bukunya. Investor kurang berminat pada saham yang terlalu mahal atau yang tidak menguntungkan. Hal inilah yang menyebabkan PBV tidak memengaruhi return saham untuk jurnal di sini. Price to book value atau PBV ialah rasio yang didapatkan dengan membandingkan harga saham emiten yang berada di pasar modal dengan nilai buku yang berasal dari laporan keuangan perusahaan yang bersangkutan Brigham \& Houston (2007:151). Rumus dari PBV ratio dapat diperoleh dengan cara menghitung komponen harga di pasar saham dibagi dengan nilai buku tiap lembar saham perusahaan (book value per share). Misal ada harga saham yang nilainya kurang dari nilai bukunya maka menurut investor, prospek saham untuk ke depannya kurang baik, sedangkan jika nilai saham suatu perusahaan lebih tinggi dibandingkan nilai bukunya maka dianggap perusahaan akan mempunyai prospek yang bagus dan kinerja yang baik.

Data pada penelitian ini dapat mendukung hasil penelitian bahwa PBV tidaklah memengaruhi return saham. Salah satu data berasal dari perusahaan Bumi Citra Permai Tbk (BCIP) yang masing-masing pada tahun 2014 sampai 2017 memiliki data PBV sebagai berikut: 4,5184; 12,3335;1,0306 dan 0,5398 dengan nilai return saham $-0,2424 ; 0,0200 ; 0,6667$ dan 0,1529 . Dengan kata lain, nilai dari PBV tidaklah memengaruhi fluktuasi atau pergerakan nilai dari return saham. Jadi data tersebut dapat menguatkan pernyataan bahwa PBV tidaklah memberikan dampak kepada return saham di dalam penelitian ini.

\section{Pengaruh Total Asset Turnover (TATO) terhadap Return Saham}

Variabel TATO memiliki hasil untuk uji t yang menyatakan bahwa Ha ditolak dan $\mathrm{H}_{0}$ diterima. Secara parsial TATO pada penelitian ini tidak memberikan dampak kepada return saham dan tidak dapat mendukung dari Signalling Theory. Jurnal yang sejalan dengan penelitian ini adalah Aditya \& Isnurhadi (2013); Bisara \& Lailatul (2015); Defawanti (2018) dan Deitiana (2011).

Lebih dari separuh sampel penelitian memiliki penjualan di atas rata-rata, akan tetapi TATO tidak bisa memberikan pengaruh terhadap fluktuasi dari return saham di pasar modal atau keinginan pemilik modal untuk menginvestasikan sahamnya kepada emiten. Hal tersebut dapat terjadi karena tingginya penjualan tidak menjamin tingginya laba yang akan dihasilkan oleh perusahaan, karena nilai penjualan tersebut belum dikurangi dengan utang, bunga dan biaya-biaya yang lain di laporan keuangan perusahaan.

Demi memperkuat pernyataan bahwa TATO tidak dapat memberikan dampak terhadap return saham, pada penelitian ini menyertakan bukti dari data penelitian yang salah satunya berasal sari perusahaan Alam Sutera Realty Tbk (ASRI). Perusahaan ASRI memiliki data dari tahun 2014 sampai 2017 TATO sebagai berikut: 0,2236 ; 0,$2432 ; 0,2336$; dan 0,2446 dengan nilai return saham 1,0744; -0,3049; 0,2903; dan 0,0727. Data perusahaan tersebut dapat memperlihatkan bahwa nilai TATO tidaklah dapat memengaruhi fluktuasi dari return saham.

\section{Pengaruh Inflasi terhadap Return Saham}

Nilai yang dihasilkan untuk uji t dari variabel inflasi memiliki nilai yang dapat menyatakan bahwa $\mathrm{H}_{0}$ ditolak dan $\mathrm{H}_{\mathrm{a}}$ diterima. Penelitian di sini memberikan hasil di mana inflasi dapat memberikan dampak kepada return saham serta membenarkan Signalling Theory. Penelitian yang mendukung dari hasil penelitian ini yaitu Hidayat (2016); Prihantini (2009) dan Rahayu \& Firmansyah (2005).

Inflasi berpengaruh negatif dan signifikan pada penelitian ini dapat terjadi karena terjadinya inflasi yang tinggi akan membuat harga produk-produk naik dan harga yang harus dibayar oleh perusahaan bisa 
Rina Nugraheni \& R.A. Sista Paramita. Pengaruh Kinerja Keuangan dan Makroekonomi terhadap Return Saham Perusahaan Property dan Real Estate di BEI Periode 2014-2017

menambah biaya/ beban yang ditanggung oleh perusahaan. Jika dana yang dikeluarkan oleh perusahaan meningkat maka akan mengurangi jumlah profit yang didapatkan. Laba yang rendah bisa mengakibatkan pemilik modal enggan untuk mengeluarkan uangnya dan berinvestasi pada emiten dan dapat mengakibatkan harga dari saham di pasar modal menjadi turun serta berakibat pada return saham yang juga menurun. Tingginya dari nilai inflasi bisa mengakibatkan membengkaknya biaya yang harus dikeluarkan untuk produksi barang oleh perusahaan bertambah mahal dan akan membuat keuntungan yang didapat perusahaan nantinya berkurang dengan biaya tersebut (Dwita \& Rahmidani, 2012).

Bukti dari data penelitian yang mendukung pernyataan sebelumnya yaitu berasal dari data inflasi dan return saham per tahun. Pergerakan nilai inflasi dari tahun 2014 sampai 2017 yaitu sebagai berikut: 0,2023; 0,$0617 ; 0,0353 ; 0,0381$ direspon dengan nilai return saham yaitu sebagai berikut: 0,4107 ; 0,$1747 ; 0,1094 ; 0,0381$. Dapat dilihat bahwa return saham mengalami fluktuasi nilai yang berbanding terbalik dengan nilai inflasi. Jadi dapat diketahui bahwa pada penelitian ini inflasi memengaruhi nilai return saham secara negatif dan signifikan.

\section{Pengaruh Nilai Tukar terhadap Return Saham}

Hasil uji t dari variabel inflasi menghasilkan nilai yang menyatakan bahwa $\mathrm{H}_{0}$ ditolak dan $\mathrm{H}_{\mathrm{a}}$ diterima. Secara parsial kurs pada hasil penelitian yang sudah dilakukan di sini menyatakan bahwa inflasi dapat memberikan dampak kepada return saham dan dapat mendukung dari Signalling Theory. Penelitian ini mendukung hasil dari penelitian Prihantini (2009) dan Amrillah (2016).

Kurs memberikan dampak secara negatif kepada return saham dapat terjadi disebabkan oleh kurs yang menguat dapat membuat biaya produksi yang dikeluarkan perusahaan menjadi lebih sedikit sehingga dapat menambah jumlah keuntungan yang nantinya na diperoleh perusahaan, sehingga harga saham dan return saham menjadi naik. Jurnal yang dapat mendukung ialah pada penelitian (Fuadi (2007) mencapai hasil penelitian di mana jika kurs rupiah turun/mahal dan mengurangi profit yang dihasilkan oleh perusahaan bisa mengakibatkan harapan dari pemilik modal akan return saham ke depannya menjadi berkurang dan membuat harga dan return saham menjadi turun, jadi kurs rupiah yang melemah mempunyai hubungan atau pengaruh yang berlawanan/negatif dengan return saham.

Data dari penelitian ini memberikan hasil penelitian yang dapat menjadi pendukung di mana kurs memengaruhi return saham secara negatif dan signifikan. Di mana pada salah satu data penelitian memperlihatkan bahwa nilai kurs per tahun dari 2014 sampai 2016 yaitu: -0,2023;0,0617;0,0353 direspon dengan nilai return saham yaitu sebagai berikut: 0,$4107 ;-0,1747 ; 0,1094$. Data tersebut memperlihatkan bahwa return saham merespon nilai kurs dengan arah terbalik atau negatif. Jadi dapat diketahui bahwa pada penelitian ini nilai kurs dapat memengaruhi nilai return saham secara negatif dan signifikan.

\section{KESIMPULAN}

Hasil studi beserta pembahasan yang telah dijelaskan dapat memberikan kesimpulan bahwa variabel bebas yang terdapat di penelitian ini yang terdiri dari Current ratio, PER, DER, PBV dan TATO tidaklah mempunyai pengaruh yang bermakna atau banyak kepada variabel terikat yaitu return saham. Sebaliknya variabel bebas yaitu makroekonomi yang terdiri dari inflasi dan nilai tukar dapat memberikan dampak atau pengaruh yang bermakna dan jelas terhadap return saham secara negatif atau berlawanan arah.

Penelitian ini menyarankan kepada perusahaan agar lebih meningkatkan kinerja keuangan agar bisa mengelola keuangannya dan menghasilkan keuntungan yang lebih baik lagi sehingga dapat memunculkan keinginan investor dalam menginvestasikan modalnya pada perusahaan atau emiten, serta lebih memperhatikan sumber utangnya terutama yang dari luar negeri karena berkaitan dengan nilai tukar yang memengaruhi return saham. Untuk investor dalam menanamkan modalnya agar lebih mempertimbangkan dampak yang bisa dihasilkan dari luar emiten karena variabel yang berasal dari luar atau eksternal pada penelitian ini terbukti memengaruhi return saham. Penelitian selanjutnya dapat melibatkan variabel-variabel yang lain baik dari laporan keuangan perusahaan ataupun makroekonomi 
yang lainnya seperti Produk Domestik Bruto (PDB) dan suku bunga, serta menambah periode penelitian yang akan digunakan.

\section{DAFTAR PUSTAKA}

Abdullah, H., Soedjatmiko, \& Sari, R. N. (2016). Pengaruh Return On Asset (ROA), Debt to Total Asset (DTA) dan Total Asset Turnover (TATO) terhadap Return Saham pada Perusahaan Property yang Terdaftar di Bursa Efek Indonesia Tahun 2011-2014. Dinamika Ekonomi Jurnal Ekonomi Dan Bisnis, 9(2), 1-17.

Aditya, K., \& Isnurhadi. (2013). Analisis Pengaruh Rasio Lancar, rasio Perputaran total Aktiva, DER, ROE, dan EPS terhadap Return Saham Perusahaan sektor Infrastruktur, Utilitas, dan Transportasi yang terdaftar di BEI Periode 2007-2011. Jurnal Manajemen Dan Bisnis Sriwijaya, 11(4), 287300 .

Alkaditiya, N. R. (2017). Pengaruh Rasio Profitabilitas , Rasio Aktivitas, Market Ratio, Firm Size Dan Bi Rate Terhadap Return ( Studi Kasus Pada Industri Rokok Yang Terdaftar Pada Bei Periode 2011-2015 ). Jurnal Eksekutif Volume 14 No. 1 Juni 2017, 14(1), 13-24.

Amrillah, M. F. (2016). Pengaruh Nilai Tukar Rupiah (Kurs), Inflasi dan Pertumbuhan Ekonomi terhadap Return Saham pada Perusahaan Perbankan yang Terdaftar di Bursa Efek Indonesia (BEI) Periode 2008 - 2014. Jurnal Valuta, 2(2), 232-250.

Anisa, N. (2015). Analisis Faktor-Faktor yang Mempengaruhi Return Saham (Studi Kasus pada Perusahaan Sub Sektor Automotive and Components yang Terdaftar di Bursa efek Indonesia Periode 2010-2014). Perbanas Review Perbanas Review Volume 1, Nomor 1, November 2015, 1 Nomor 1(November), 72-86.

Arista, D., \& Astohar. (2012). Analisis Faktor-Faktor yang Mempengaruhi Return Saham (Kasus pada Perusahaan Manufaktur yang Go Public di BEI periode tahun 2005 - 2009). Jurnal Ilmu Manajemen Dan Akuntansi Terapan, Vol 3 Nomor 1, Mei 2012, 3(1), 1-15.

Artaya, M., Purbawangsa, I. B. A., \& Artini, L. G. S. (2014). Pengaruh Faktor Ekonomi Makro, Risiko Investasi Dan Kinerja Keuangan Terhadap Return Saham Perusahaan Di Bursa Efek Indonesia (Bei). E-Jurnal Ekonomi Dan Bisnis Universitas Udayana 3.12 (2014) : 689-701, 12, 689-701.

Bisara, C., \& Lailatul, A. (2015). Pengaruh Kinerja Keuangan Terhadap Return Saham. Jurnal Ilmu \& Riset Akuntansi, 4(2), 1-14.

BPS. (2019). Badan Pusat Statistik. (https://www.bps.go.id/subject/3/inflasi.html/, diakses pada tanggal 1 Desember 2019).

Brigham, E. F., \& Houston, J. F. (2007). Dasar-Dasar Manajemen Keuangan (11th ed.). Jakarta: Salemba Empat.

Budialim, G. (2013). Pengaruh Kinerja Keuangan dan Risiko terhadap Return Saham Perusahaan Sektor Consumer Goods Di Bursa Efek Indonesia Periode 2007 - 2011. Jurnal Ilmiah Mahasiswa Universitas Surabaya Vol.2 No.1 (2013), 2(1), 1-23.

Carlo, M. A. (2014). Pengaruh ROE, DPR, dan PER pada Return Saham. E-Jurnal Akuntansi Universitas Udayana, 1(7), 151-164.

Defawanti, A. R. (2018). Pengaruh Kinerja Keuangan, Tingkat Bunga dan Inflasi terhadap Return Saham Perusahaan Sektor Property dan Real Estate yang Terdaftar di Bursa Efek Indonesia Periode 2014-2016. Jurnal Ilmu Manajemen, 6(3), 183-196. 
Rina Nugraheni \& R.A. Sista Paramita. Pengaruh Kinerja Keuangan dan Makroekonomi terhadap Return Saham Perusahaan Property dan Real Estate di BEI Periode 2014-2017

Deitiana, T. (2011). Pengaruh rasio keuangan, pertumbuhan penjualan dan dividen terhadap harga saham. Jurnal Bisnis Dan Akuntansi, 13(1), 57-66.

Dwita, V., \& Rahmidani, R. (2012). Pengaruh Inflasi, Suku Bunga dan Nilai Tukar terhadap Return Saham Sektor Restoran Hotel dan Pariwisata. Jurnal Kajian Manajemen Bisnis, 1(1), 59-74.

Effendi, E. S., \& Hermanto, S. B. (2017). Pengaruh Rasio Keuangan dan Volume Perdagangan Terhadap Return Saham. Jurnal Ilmu Dan Riset Akuntansi, 6(November).

Erari, A. (2014). Analisis Pengaruh Current Ratio , Debt To Equity Ratio , dan Return On Asset Terhadap Return Saham Pada Perusahaan Pertambangan di Bursa Efek Indonesia. Jurnal Manajemen \& Bisnis, 5(2), 174-191.

Fuadi, D. W. (2007). Analisis Pengaruh Suku Bunga, Volume Perdagangan dan Kurs Terhadap Return Saham Sektor Properti yang Listed di BEI ( Studi Kasus Pada Saham Sektor Properti yang Listed di BEI Periode 2003-2007 ). Jurnal Bisnis Dan Strategi, 18(1), 114-129.

Ghozali, I. (2016). Aplikasi Analisis Multivariate dengan Program IBM SPSS 23. (P. P. Harto, Ed.) (8th ed., Vol. 8). Semarang: Badan Penerbit Universitas Diponegoro.

Hanurat, A. I. (2013). Pengaruh Karakteristik Perusahaan dan Ekonomi Makro terhadap return Saham Syariah yang Listing di Jakarta Islamic Index (JII). Jurnal Manajemen Dan Bisnis, 3(2), 115134. https://doi.org/10.1017/CBO9781107415324.004

Hayati, N. (2010). Faktor - Faktor yang Memengaruhi Price Earning Ratio (PER) Sebagai Salah Satu Kriteria Keputusan Investasi Saham Perusahaan Real Estate dan Property di Bursa Efek Indonesia. Jurnal Manajemen Dan Akuntansi, 11(April), 53-62.

Hidayat, S. N. (2016). Pengaruh Karakteristik Keuangan, Ukuran Perusahaan, dan Inflasi terhadap Return Saham. Jurnal Profita Edisi 6 Tahun 2016, 3, 1-11.

Husein, F., \& Mahfud, M. K. (2015). Analisis Pengaruh Distress Risk , Firm Size , Book To Market Ratio , Return on Assets , Dan Debt Equity Ratio Terhadap Return Saham. Diponegoro Journal of Management Volume 4, Nomor 3, Tahun 2015, Halaman 1-15, 4(3), 1-15.

IDX. (2019). Indonesia Stock Exchange. (https://www.idx.co.id/, diakses pada tanggal 3 Desember 2019).

IDX. (2019). Yuk Nabung Saham. (http://yuknabungsaham.idx.co.id/, diakses pada tanggal 10 Desember 2019).

Karim, A. (2015). Analisis Pengaruh Faktor Internal Dan Eksternal Terhadap Return Saham Perusahaan Manufaktur Yang Terdaftar Di Bursa Efek Indonesia (BEI) Periode 2010-2012. Jurnal Media Ekonomi Dan Manajemen Vol. 30 No. 1 Januari 2015, 30(1), 41-55.

Kasmir. (2014). Pengantar Manajemen Keuangan (Kedua). Jakarta: Prenada Media.

Khan, R. M. (2017). Factors Influencing Stock Returns in Listed Firms of Karachi Stock Exchange. Journal of Commerce, Economics, and Social Sciences, 11(2), 248-251. https://doi.org/10.24312/paradigms110219

Kurniadi, A., Achsani, N. A., \& Sasongko, H. (2013). Kinerja Keuangan Berbasis Penciptaan Nilai, Faktor Makroekonomi dan Pengaruhnya Terhadap Return Saham Sektor Pertanian. Jurnal Akuntansi Dan Keuangan. https://doi.org/10.9744/jak.15.2.63-74 
Mahilo, M. B. (2015). Dampak Risiko Bunga, Inflasi, dan Kurs terhadap Return Saham Perusahaan Makanan Dan Minuman Yang Go Public Di Bursa Efek Indonesia. Jurnal Emba ISSN 2303-1174 Vol.3 No.3 Sept. 2015, Hal. 1-10, 3(3), 1-10.

Marlina, D., \& Sari, E. N. (2009). Pengaruh Rasio Profitabilitas Dan Leverage Terhadap Return Saham (Studi Empiris Perusahaan Manufaktur Di Bei). Jurnal Riset Akuntansi \& Bisnis, 9(1), 80-105. https://doi.org/10.1016/j.neurobiolaging.2012.03.001\rS0197-4580(12)00181-9 [pii]

Martani, D., Mulyono, \& Khairurizka, R. (2009). The effect of financial ratios, firm size, and cash flow from operating activities in the interim report to the stock return. Chinese Business Review, ISS? 1537-1506, USA Jun. 2009, Volume 8, No.6 (Serial No.72), 8(6), 1537-1506.

Mathilda, M. (2012). Pengaruh Price Earning Ratio dan Price Book Value terhadap Harga Saham Indeks LQ 45 (Periode 2007-2009). Jurnal Akuntansi Vol.4 No.1 Mei 2012: 1-21, 4(1), 1-21.

Nuryana, I. (2013). Pengaruh Rasio Keuangan Terhadap Return Saham Perusahaan LQ45 di Bursa Efek Jakarta. Jurnal Akuntansi Aktual, Vol. 2, Nomor 2, Juni 2013, Hlm. 57-66, 2(1), 1-18. Retrieved from https://ojs.unud.ac.id/index.php/Akuntansi/article/view/4302

OJK. (2019). Statistik Pasar Modal Indonesia. (https://www.ojk.go.id/id/kanal/pasar-modal/data-danstatistik/statistik-pasar-modal/Default.aspx, diakses pada tanggal 5 Desember 2019).

Prasetioningsih, D., Taunay, E. G. P., \& Fathoni, A. (2015). Pengaruh Nilai Tukar Rupiah Terhadap Return saham yang Terdaftar di Bursa Efek Indonesia 9Studi Kasus Perusahaan LQ45 Periode Januari 2012 - Desember 2015).

Prasetyorini, B. F. (2013). Pengaruh Ukuran Perusahaan, Leverage, Price Earning Ratio dan Profitabilitas terhadap Nilai Perusahaan. Jurnal Imu Manajemen|Volume 1 Nomor 1 Januari 2013,1 .

Prihantini, R. (2009). Analisis Pengaruh Inflasi, Nilai tukar, ROA, DER dan CR Terhadap Return Saham (Studi Kasus Saham Industri Real Estate an Property yang Terdaftar di BEI Periode 2003 - 2006). Jurnal Bisnis Dan Strategi, 18(2), 99-111.

Rahayu, D. S., \& Firmansyah. (2005). Estimasi pengaruh Inflasi dan Tingkat Output Terhadap Return dan Volatilitas Saham di Indonesia (Pendekatan Model Garch, Tarch dan Egarch). Jurnal Bisnis Strategi, 14(1), 95-109.

Rahman, M. H., \& Arfianto, E. D. (2016). Analisis Pengaruh Variabel Leading Economic Indicator ( LEI ) Dan Coincident Economic Indicator ( CEI ) Terhadap Return Saham Jakarta Islamic Index ( JII). Diponegoro Journal of Management Volume 5, Nomor 1, Tahun 2016, Halaman 1-14, 5 , $1-14$.

Riantani, S., \& Tambunan, M. (2013). Analisis Pengaruh Variabel Makroekonomi dan Indeks Global terhadap Return Saham. Seminar Nasional Teknologi Informasi \& Komunikasi Terapan 2013, 532-537.

Rusliati, E., \& Fathoni, N. (2011). Inflasi, Suku Bunga Deposito dan Return Pasar terhadap Return Saham pada Industri Barang Konsumsi yang Terdaftar di BEI 2006-2009. Jurnal Bisnis Dan Akuntansi Vol. 13, No. 2, Agustus 2011, Hlm. 107 - 118, 13(2), 107-118.

Sugiarto, A. (2011). Analisa Pengaruh Beta, Size Perusahaan, DER dan PBV Ratio Terhadap Return Saham. Jurnal Dinamika Akuntansi, 3(1), 8-14.

Suherman, \& Siburian, A. (2013). Pengaruh Earning Per Sahre, Debt to Equity Ratio, Return On Equity, 
Rina Nugraheni \& R.A. Sista Paramita. Pengaruh Kinerja Keuangan dan Makroekonomi terhadap Return Saham Perusahaan Property dan Real Estate di BEI Periode 2014-2017

dan Price To Book Value Terhadap Return Saham (Studi Kasus Pada Perusahaan Industry Food and Beverages yang Terdaftar di Bursa Efek Indonesia). Jurnal Riset Manajemen Sains Indonesia (JRMSI), 4(1), 16-30.

Sukirno, S. (2010). Makroekonomi Teori Pengantar. Jakarta: Rajawali Pers.

Sunardi, H. (2010). Pengaruh Penilaian Kinerja dengan ROI dan EVA terhadap Return Saham pada Perusahaan yang Tergabung dalam Indeks LQ 45 di Bursa Efek Indonesia. Jurnal Akuntansi Vol.2 No.1 Mei 2010: 70-92, 2(1), 70-92.

Sutriani, A. (2014). Pengaruh Profitabilitas, Leverage, dan Likuiditas terhadap Return Saham dengan Nilai Tukar Sebagai Variabel Moderasi Pada Saham LQ-45. Journal of Business and Banking Volume 4, No. 1, May 2014, Pages 67 -80, 4(1), 67-80.

Tandelilin, E. (2010). Portofolio dan Investasi Teori dan Aplikasi (1st ed.). Yogyakarta: Kanisius.

Ulupui, I. G. K. A. (2007). Analisis Pengaruh Rasio Likuiditas, Leverage, Aktivitas, Dan Profitabilitas Terhadap Return Saham (Studi Pada Perusahaan Makanan Dan Minuman Dengan Kategori Industri Barang Konsumsi Di BEJ). Jurnal Ilmiah Akuntansi Dan Bisnis, 1-20. https://doi.org/10.1017/CBO9781107415324.004

Wiradharma, M. S., \& Sudjarni, L. K. (2016). Pengaruh Tingkat Suku Bunga, Tingkat Inflasi, Nilai Kurs Rupiah dan Produk Domestik Bruto terhadap Return Saham. E- Jurnal Manajemen Unud Vol. 5, No. 6, 2016: 3392-3420, 5(6), 3392-3420.

Yunita, R., Efni, Y., \& Kamaliah. (2016). Pengaruh Faktor Internal dan faktor Makro-Ekonomi terhadap Return Saham dengan Beta Saham sebagai Variabvel Intervening (Studi Kasus pada Perusahaan Property dan Real Estate dan Building Construction yang Terdaftar di BEI Tahun 2012-2016. ISSN 2549-5704, (6), 44-58.

Zakaria, A. A. (2015). Pengaruh Nilai Pasar, Profitabilitas, Economic Value Added, dan Inflasi terhadap Return Saham Perusahaan Sektor Keuangan yang Terdaftar Di Bursa Efek Indonesia Periode 2013-2015. Jurnal Llmu Manajemen Volume 5 Nomor 3 - Jurusan Manajemen Fakultas Ekonomi Universitas Negeri Surabaya, 5, 1-10. 